\title{
Contributions on the Sensorial, Physico-chemical and Nutritional Characterization of Hare Meat (Lepus europaeus pallas)
}

\author{
GABRIELA FRUNZA ${ }^{1}$, DANIEL SIMEANU ${ }^{1 *}$, CECILIA POP ${ }^{1 *}$, ROXANA LAZAR $^{1}$, PAUL CORNELIU BOISTEANU ${ }^{1}$, MARCELA STEFAN ${ }^{2}$ \\ ${ }^{1}$ University of Agricultural Sciences and Veterinary Medicine of Iasi, 3 Mihail Sadoveanu Alley, 700490 lasi, Romania \\ 2 The Bucharest University of Economic Studies, 6 Romana Sq., 010374, Bucharest, Romania
}

\begin{abstract}
The growing demand for food worldwide, along with the increasing need for animal protein, lead to the identification of other sources of highest quality meat, then the conventional ones, such as it is the hare meat. The aim of this study was to characterize the sensorial, physico-chemical and nutritional traits of hare meat (Lepus europaeus Pallas) issued from hunting funds in North-East of Romania. The biological material consisted of 79 hares (34 males and 45 females), slaughtered by shooting at the age of about 18 months, during the regular hunting season (1 November to 31 January). Different muscle groups were collected: Longissimus dorsi (LD), Triceps brachi (TB) and Semimembranosus (SM). For physicochemical determinations (measurement of the $\mathrm{pH}$ at 24 and 48 hours, of water, proteins, lipids, fatty acids and of ash) were analyzed 237 samples ( 79 for each muscle group). The results obtained from the sensory analysis are relatively close as a score for the three muscle groups studied. The $\mathrm{pH}$ value was higher for TB muscles. The highest amount of protein was observed for $L D$ muscles collected from males (21.65\%), while the richest in lipids were the females TB muscles (2.38\%). The fatty acids levels were predominantly higher for males (for the most of the assessed fatty acids). Very favorable ratio of PUFA:SFA was identified in LD muscles (1.695 for males and 1.531 for females), in SM muscles (1.679 for males and 1.527 for females), and in TB muscles, as well (1.885 for males and 1.820 for females). The variance analysis revealed insignificant gender related differences for the three muscle groups, concerning the sensorial traits, the pH level, ash content and energy value. However, in proteins, lipids and water levels, there were observed highly significant gender related differences in TB muscles. Also, for some fatty acids, significant statistical differences were found between genders, in all three muscle groups.
\end{abstract}

Keywords: hare meat, fatty acids, proteins, lipids.

Due to the growing demand for high-quality meat products, the challenges of the meat industry are to meet consumer expectations of delivering safe, high-quality meat [1, 2]. Modern consumers expect to have access to softand tender meat, with good taste, high nutritional value (rich in proteins, minerals, unsaturated fatty acids and vitamins), inducing positive influences on human health [3-18], safe for consumption, without pesticides, antibiotics and drug residues $[19,20]$. The consumers desire, as well, new types of food [21, 22].

The meat products are appreciated by consumers, thus there is an increasing demand of those commodities issued from farming systems observing high standards of animal welfare [23]. The attention of farmers and meat producers has been focused on small mammals, such as domestic rabbits (Oryctolagus cuniculus), which provide high quality meat [23-50]. Another leporid species, the brown hare (Lepus europaeus Pallas), has also been generating interest from meat producers $[2,19,51]$. The meat of these animals differs from that of poultry and other farmyard animals [52], but the consumption of their meat is not so popular as other [19, 52]. Rabbit meat is healthier than other meats frequently used in human nutrition, such as chicken, beef, and pork [53], being easily digested, lean and rich in proteins (with high levels of essential amino acids), unsaturated lipids ( $\omega 3$ and $\omega 6$ ), B vitamins, potassium, phosphorus and magnesium, low in sodium and cholesterol and very poor in uric acid [22-50, 54-61].

The brown hare (Lepus europaeus Pallas) is one of the most popular small game species [20] being sometime reared for the restocking of hunting and protected areas in Europe $[2,20,51]$. Some authors have investigated the potential of adding hare meat from hunting into the human diet because of its favorable sensory characteristics, high unsaturated fatty acids [57], proteins, minerals, vitamins content and low-fat content [58,60,61] and its energetic value which is similar to other meats [51]. Hare meat is classified as red meat, mainly in terms of its high iron (Fe) content [61], but its availability is usually restricted by hunting seasons [52,57,60]. To produce high-quality meat, it is necessary to understand the characteristics of meat quality traits and the factors that control them but in wild animals is quite difficult to establish the influence of diet on meat characteristics $[2,52]$. Hares, like wild rabbits, are herbivorous that consume a wide variety of plants and grains that qualitatively and nutritionally differ by season, which may cause large variation in the composition of the meat [59].

There are very few data available in the literature regarding the characterization of hare meat. From our knowledge only three articles approached the quality of hare meat issued from hunting, in Austria [57], in Croatia [60], and in Slovakia [58]; another three recent studies depict the quality of hare meat collected from farmed brown hare in Italy [20,51], and Poland [2]. The lack of data on the characterization of hare meat led us to carry on this study, whose goals were to assess the sensorial, physico-chemical and nutritional traits of hare meat (Lepus europaeus Pallas) collected from hunting funds in NorthEast of Romania.

\section{Experimental part}

Materials and methods

The biological material consisted of 79 hare individuals (34 males and 45 females), slaughtered by shooting at the

\footnotetext{
* email: dsimeanu@uaiasi.ro; cicipop@uaiasi.ro
} 
age of about 18 months, during the regular hunting season (1 November to 31J anuary). Three different muscle groups (LD - Longissimus dorsi, SM - Semimembranosus and TB - Triceps brachii muscles) were collected, due to their different physical-chemical properties, different metabolic type and in order to cover the main anatomical regions of the carcasses, as well (back -LD, hind leg-SM, foreleg TB). The muscles on the right side of the carcass were used, to assess the physical-chemical traits (measurement of $\mathrm{pH}$ at 24- and 48-h post-slaughter, of water, proteins, lipids, fatty acids and ash contents), summarizing 237 samples ( 79 for each muscle group). They were preliminary fine grinded and homogenized using an electric shredder. The muscle groups on the left side of the carcasses (237 samples, individually packaged, vacuumed and then prepared for one hour at a constant temperature of $80^{\circ} \mathrm{C}$ in a water bath), were used for sensory analyses and performed by tasting. After cooling, the samples were cut and given to 23 tasters, trained in advance. The assessment sheets of the sensory characteristics were filled in using a five-point hedonic scale (scores from 1 to 5 ), in which one point represented the not favourable features, while 5 points indicated the characteristics which fully satisfied the requirements of the tasters. For example: the extremely pale colour was noted with 1 , while the intense red colour was noted with 5; global assessment was scored with 1 for unacceptable meat, with two points for acceptable meat, with three points for good meat, with four points for very good meat and with five points for exceptional meat. For two consecutive days after slaughter, meat $\mathrm{pH}$ value was measured, using the digital $\mathrm{pH}$ meter Hanna Electronics, type 212 , on chilled samples, at $2^{\circ} \mathrm{C}$. The water, protein and lipid content were determined using the Food Check Near Infrared Spectrophotometer (NIRS technology); the energy value was determined by calculation using conventional formulas and crude ash content was assessed by calcinations (at $550^{\circ} \mathrm{C}$ for $16 \mathrm{~h}$ after a preliminary carbonization) [62-64]. Using the FOSS 6500 spectrophotometer (NIRS technology), the assessment of fatty acids content was performed. The freshly ground samples were placed in sterile Petri dishes, weighed, then lyophilized at $-110^{\circ} \mathrm{C}$ for $24 \mathrm{~h}$, using the CoolSafe ${ }^{\mathrm{TM}}$, SCANVAC lyophilizer, weighed again and then vacuumed (in special bags) and stored in a freezer at a temperature of $-80^{\circ} \mathrm{C}$ until the moment of their analysis. The following saturated fatty acids (SFA) were assessed: C14:0 (myristic acid), C15:0 (pentadecanoic acid), C16:0 (palmitic acid) C17:0 (heptadecanoic acid) and C18:0 (stearic acid). Among the monounsaturated fatty acids (MUFA, $\omega 7$ and $\omega 9$ ) there were investigated: C18:1n-7 (vaccenic acid cis isomer of oleic acid) and C18:1n-9 (oleic acid); a total of nine polyunsaturated fatty acids (PUFA, $\omega 3$ and $\omega 6$ ) were also assessed: C18:2n-6 (linoleic), C18:3n-3 (linolenic), C20:2n-6 (eicosadienoic), C20:3n-6 (eicosatrienoic), C20:4n-6 (arachidonic), C20:5n-3 (eicosapentaenoic or EPA), C22:4n-6 (docosatetraenoic), C22:5n-3 (docosapentaenoic or DPA) and C22:6n-3 (doco-sahexaenoic or DHA) [65-81]. All the achieved results were statistically processed through the main descriptors computation and analysis of variance test (Anova single factor), using the GraphPad Prism 7.0 software.

\section{Experimental part}

Following sensory appreciation of hare meat (Lepus europaeus Pallas) it could be noted a higher score of meat color (table 1), with more than 4.14 points for all muscle groups analyzed, for both females and males (4.14 for females in the LD muscles and 4.36 for males in SM muscles). The highest accumulated score for hare meat color was based on the more intense red hue specific to game meat. It is observed that the lowest color values were obtained for the LD muscles compared to the TB and SM muscles, similar results being observed in other studies: in farmed brown hares, the redness index increased at the hind leg, while it decreased in LD muscles, by age [20]. For the other analyzed sensory characteristics, a slightly higher score for males has been achieved. In SM muscles predominated a higher score for most of the evaluated characteristics, except for Fibrous appearance, where a lower score ( 3.00 for females and 3.07 for males) has been obtained, because muscle fibers are thinner compared to TB muscles and LD muscles. Generally speaking, the values obtained were relatively close for all studied muscles, with some small differences for certain characteristics, and the statistical analysis revealed insignificant differences between genders.

Table 1

SENSORIAL SCORES OF LONGISSIMUSDORSI, SEMIMEMBRANOSUS AND TRICEPSBRACHII MUSCLES

\begin{tabular}{|c|c|c|c|c|c|c|c|c|c|c|}
\hline \multirow{2}{*}{ Traits } & \multirow{2}{*}{$\mathbf{M} / \mathbf{F}^{*}$} & \multicolumn{3}{|c|}{ LD } & \multicolumn{3}{|c|}{ SM } & \multicolumn{3}{|c|}{ TB } \\
\hline & & $\bar{x} \pm s_{\bar{x}}$ & V\% & Anova & $\bar{x} \pm s_{\bar{x}}$ & $\mathrm{~V} \%$ & Anova & $\bar{x} \pm s_{\bar{x}}$ & $\mathrm{~V} \%$ & Anova \\
\hline \multirow{2}{*}{ Colour } & $\mathrm{M}$ & $4.16 \pm 0.13$ & 17.52 & \multirow{2}{*}{$\begin{array}{c}\text { n.s. } \\
\mathrm{p}=0.121\end{array}$} & $4.36 \pm 0.09$ & 11.20 & \multirow{2}{*}{$\begin{array}{c}\text { n.s. } \\
p=0.514\end{array}$} & $4.22 \pm 0.27$ & 7.12 & \multirow{2}{*}{$\begin{array}{c}\text { n.s. } \\
\mathrm{p}=0.182\end{array}$} \\
\hline & $F$ & $4.14 \pm 0.17$ & 13.84 & & $4.15 \pm 0.12$ & 15.70 & & $4.19 \pm 0.14$ & 3.44 & \\
\hline \multirow{2}{*}{$\begin{array}{c}\text { Fibrous } \\
\text { appearance }\end{array}$} & $\mathrm{M}$ & $3.70=0.16$ & 30.50 & \multirow{2}{*}{$\begin{array}{c}\text { n.s. } \\
\mathrm{p}=0.283\end{array}$} & $3.07 \pm 0.14$ & 23.32 & \multirow{2}{*}{$\begin{array}{c}\text { n.s. } \\
\mathrm{p}=0.652\end{array}$} & $3.51 \pm 0.19$ & 3.22 & \multirow{2}{*}{$\begin{array}{c}\text { n.s. } \\
\mathrm{p}=0.128\end{array}$} \\
\hline & $\mathrm{F}$ & $3.76 \pm 0.20$ & 26.46 & & $3.00 \pm 0.10$ & 18.14 & & $3.46 \pm 0.20$ & 6.76 & \\
\hline \multirow[b]{2}{*}{ Scent } & $\mathrm{M}$ & $4.05 \pm 0.19$ & 21.90 & \multirow{2}{*}{$\begin{array}{c}\text { n.s. } \\
\mathrm{p}=0.435\end{array}$} & $4.00 \pm 0.13$ & 16.67 & \multirow{2}{*}{$\begin{array}{c}\text { n.s. } \\
\mathrm{p}=0.531\end{array}$} & $4.15 \pm 0.12$ & 1.80 & \multirow{2}{*}{$\begin{array}{c}\text { n.s. } \\
\mathrm{p}=0.171\end{array}$} \\
\hline & $\mathrm{F}$ & $3.90=0.16$ & 17.94 & & $3.96 \pm 0.07$ & 9.24 & & $4.11 \pm 0.18$ & 7.34 & \\
\hline \multirow{2}{*}{ Taste } & $\mathrm{M}$ & $4.15 \pm 0.21$ & 17.96 & \multirow{2}{*}{$\begin{array}{c}\text { n.s. } \\
\mathrm{p}=0.643\end{array}$} & $4.21 \pm 0.13$ & 16.28 & \multirow{2}{*}{$\begin{array}{c}\text { n.s. } \\
\mathrm{p}=0.243\end{array}$} & $4.06 \pm 0.23$ & 7.22 & \multirow{2}{*}{$\begin{array}{c}\text { n.s. } \\
\mathrm{p}=0.127\end{array}$} \\
\hline & $\mathrm{F}$ & $3.86 \pm 0.22$ & 26.29 & & $4.00 \pm 0.15$ & 19.25 & & $3.98 \pm 0.27$ & 6.78 & \\
\hline \multirow{2}{*}{ Flavour } & $\mathrm{M}$ & $3.83 \pm 0.12$ & 15.45 & \multirow{2}{*}{$\begin{array}{c}\text { n.s. } \\
\mathrm{p}=0.732\end{array}$} & $3.64 \pm 0.09$ & 13.39 & \multirow{2}{*}{$\begin{array}{c}\text { n.s. } \\
\mathrm{p}=0.325\end{array}$} & $3.87 \pm 0.17$ & 5.66 & \multirow{2}{*}{$\begin{array}{c}\text { n.s. } \\
\mathrm{p}=0.453\end{array}$} \\
\hline & $\mathrm{F}$ & $3.67 \pm 0.18$ & 21.70 & & $3.57 \pm 0.10$ & 14.11 & & $3.77 \pm 0.16$ & 1.90 & \\
\hline \multirow{2}{*}{$\begin{array}{l}\text { Intensity of } \\
\text { the flavor }\end{array}$} & $\mathrm{M}$ & $3.90=0.16$ & 18.41 & \multirow{2}{*}{$\begin{array}{c}\text { n.s. } \\
p=0.546\end{array}$} & $4.29 \pm 0.13$ & 16.63 & \multirow{2}{*}{$\begin{array}{c}\text { n.s. } \\
p=0.357\end{array}$} & $3.97 \pm 0.19$ & 8.55 & \multirow{2}{*}{$\begin{array}{c}\text { n.s. } \\
\mathrm{p}=0.313\end{array}$} \\
\hline & $\mathrm{F}$ & $3.71 \pm 0.06$ & 24.29 & & $4.00 \pm 0.15$ & 19.25 & & $3.89 \pm 0.09$ & 14.34 & \\
\hline \multirow{2}{*}{ Succulence } & $\mathrm{M}$ & $3.43 \pm 0.19$ & 24.74 & \multirow{2}{*}{$\begin{array}{c}\text { n.s. } \\
\mathrm{p}=0.343\end{array}$} & $3.79 \pm 0.13$ & 18.13 & \multirow{2}{*}{$\begin{array}{c}\text { n.s. } \\
\mathrm{p}=0.133\end{array}$} & $3.23 \pm 0.17$ & 4.64 & \multirow{2}{*}{$\begin{array}{c}\text { n.s. } \\
p=0.265\end{array}$} \\
\hline & $\mathrm{F}$ & $3.43 \pm 0.16$ & 21.77 & & $3.86 \pm 0.12$ & 16.87 & & $3.33 \pm 0.22$ & 1.57 & \\
\hline \multirow{2}{*}{ Tendemess } & $\mathrm{M}$ & $3.70 \pm 0.21$ & 24.96 & n.s. & $4.00 \pm 0.16$ & 21.52 & $\mathrm{~ns}$ & $3.64 \pm 0.27$ & 4.44 & n.s. \\
\hline & $\mathrm{F}$ & $3.62 \pm 0.25$ & 28.28 & $\mathrm{p}=0.260$ & $3.97 \pm 0.16$ & 21.99 & $\mathrm{p}=0.015$ & $3.67 \pm 0.29$ & 8.33 & $\mathrm{p}=0.213$ \\
\hline Overall & $\mathrm{M}$ & $4.20=0.12$ & 12.46 & n.s. & $4.19 \pm 0.10$ & 13.61 & & $4.07 \pm 0.15$ & 2.99 & n.s. \\
\hline appreciation & $\mathrm{F}$ & $3.95 \pm 0.19$ & 20.36 & $\mathrm{p}=0.234$ & $4.14 \pm 0.07$ & 8.60 & $\mathrm{~ns} p=0.276$ & $3.98 \pm 0.17$ & 2.56 & $\mathrm{p}=0.351$ \\
\hline
\end{tabular}

$\overline{\mathrm{M} / \mathrm{F}}=$ Males/Females; n.s. (not ignificant) $=\mathrm{p}>0.05 ;{ }^{*}$ (significant) $=0.05>\mathrm{p}>0.01 ;$

${ }^{* *}($ distinct significant $)=0.01>p>0.001 ; * * *($ highly significant $)=0.001>p$. 


\begin{tabular}{|c|c|c|c|c|c|}
\hline Muscles & Period & $\mathrm{M} / \mathrm{F}^{*}$ & $\bar{x} \pm s_{\bar{x}}$ & $V \%$ & Anova \\
\hline \multirow{4}{*}{$L D$} & \multirow{2}{*}{$24 \mathrm{~h}$} & $\mathrm{M}$ & $5.637 \pm 0.019$ & 0.807 & \multirow{2}{*}{$\begin{array}{c}\mathrm{p}=0.227 \\
\text { n.s. }\end{array}$} \\
\hline & & F & $5.623=0.029$ & 1.041 & \\
\hline & \multirow{2}{*}{$48 \mathrm{~h}$} & $\mathrm{M}$ & $5.641 \pm 0.019$ & 0.807 & $\mathrm{p}=0.352$ \\
\hline & & $\mathrm{F}$ & $5.688 \pm 0.052$ & 1.841 & n.s. \\
\hline \multirow{4}{*}{$S M$} & \multirow{2}{*}{$24 \mathrm{~h}$} & $\mathrm{M}$ & $5.687 \pm 0.019$ & 0.799 & $\mathrm{p}=0.324$ \\
\hline & & $\mathrm{F}$ & $5.683 \pm 0.311$ & 1.388 & n.s. \\
\hline & \multirow{2}{*}{$48 \mathrm{~h}$} & $\mathrm{M}$ & $5.732=0.024$ & 1.043 & $\mathrm{p}=0.124$ \\
\hline & & F & $5.805 \pm 0.062$ & 2.135 & n.s. \\
\hline \multirow{4}{*}{$T B$} & \multirow{2}{*}{$24 \mathrm{~h}$} & $\mathrm{M}$ & $6.062=0.028$ & 1.135 & $\mathrm{p}=0.154$ \\
\hline & & $\mathrm{F}$ & $6.003=0.082$ & 2.729 & n.s. \\
\hline & \multirow{2}{*}{$48 \mathrm{~h}$} & $\mathrm{M}$ & $6.102 \pm 0.027$ & 1.104 & $\mathrm{p}=0.658$ \\
\hline & & $\mathrm{F}$ & $6.173 \pm 0.031$ & 1.002 & n.s. \\
\hline
\end{tabular}

$\mathrm{M} / \mathrm{F}=$ Males $/$ Females; n.s. (not significant) $=\mathrm{p}>0.05^{* *}$ (significant) $=0.05>\mathrm{p}>$ $0.01 ; * *$ (distinct significant) $=0.01>p>0.001 ; * * *$ (highly significant) $=$ $0.001>\mathrm{p}$.

\begin{tabular}{|c|c|c|c|c|}
\hline Muscles & Gender & $\bar{x} \pm s_{\bar{x}}$ & $\mathrm{~V} \%$ & Anova \\
\hline \multirow{2}{*}{ SM } & Females & $21.58=0.05$ & 0.44 & \multirow{2}{*}{$\begin{array}{c}\mathrm{p}=0.684 \\
\text { n.s. }\end{array}$} \\
\hline & Males & $21.60=0.04$ & 0.41 & \\
\hline \multirow{2}{*}{ LD } & Females & $21.53=0.09$ & 0.88 & \multirow{2}{*}{$\begin{array}{c}\mathrm{p}=0.279 \\
\text { n.s. }\end{array}$} \\
\hline & Males & $21.65=0.06$ & 0.70 & \\
\hline \multirow{2}{*}{ TB } & Females & $21.38=0.03$ & 0.23 & \multirow{2}{*}{$\begin{array}{c}\mathrm{p}=0.005 \\
* *\end{array}$} \\
\hline & Males & $21.52=0.04$ & 0.46 & \\
\hline
\end{tabular}

Table 2

THE $p H$ OF HARE MEAT AT 24H AND 48H POST SLAUGHTERING

$\mathrm{M} / \mathrm{F}=$ Males/Females; $\mathrm{n.s}$. (not significant) $=\mathrm{p}>0.05$

$*$ (significant) $=0.05>p>0.01 ; * *$ (distinct significant) $=0.01>p>0.001 ; * * *$ (highly significant) $=0.001>\mathrm{p}$.

Variance analysis showed not significant differences between genders related to hare meat $\mathrm{pH}$ level (table 2). Higher values for TB muscles were observed compared to the other muscles $(6.003$ at $24 \mathrm{~h}, 6.173$ at $48 \mathrm{~h}$ in females and 6.062 at $24 \mathrm{~h}, 6.102$ at $48 \mathrm{~h}$ in males). At $48 \mathrm{~h}$ after slaughter, at the level of the three muscle groups studied, it was observed that in female's $\mathrm{pH}$ had higher values than those measured in males, even if at 24 hours the highest $\mathrm{pH}$ values were recorded for males. These results are in line with other studies carried on sub-adult and adult reproducing farmed hares [19], that found the $\mathrm{pH}$ of hind leg (5.74 to 5.83) and LD (5.53 to 5.69) increased with age. Mertin et al., 2012 [58] found in LD muscles of hunted hares a $p H$ value of 6.17 at $48 \mathrm{~h}$. Kroliczewska et al., 2018 [2] comparing the meat of rabbit with that of hares, found the higher $\mathrm{pH}$ of meat for hares (average of 6.11 from: 6.15 in fore leg muscles, 6.12 in hind leg muscles and 6.07 in LD muscles); the highest $\mathrm{pH}$ values were observed for the fore legs and the lowest were observed for the LD, which are in accordance with our results. The high $\mathrm{pH}$ values in hare meat are explained as a result of the stressful conditions at slaughter and the higher levels of physical activity before the hare individuals were shot, resulting in the exhaustion of muscle glycogen stores prior to death. Furthermore, muscle glycogen level at death largely determines the ultimate $\mathrm{pH}\left(\mathrm{pH}_{4}\right)$ [82]. Króliczewska et al., 2018 [2] specifies that the $\mathrm{pH}$ measurement methodology used in their conducted study (samples delivered to the laboratory within 30 min after slaughter, placed in polyethylene bags, frozen at $-20^{\circ} \mathrm{C}$ for $30 \mathrm{~min}$, and stored at $-80^{\circ} \mathrm{C}$ until analysis), don't measure the real $\mathrm{pH}_{u}$ ( $24 \mathrm{~h}$ postmortem/24 h chilling) and probably not fully depleted glycogen may cause observed higher $\mathrm{pH}$ values in muscles.

Hare meat was also characterized by its chemical components (proteins, lipids, fatty acids, water and mineral substances - crude ash). The proteins content has the highestaverage values at the level of LD muscles for males, $21.65 \%$. For the other muscle groups, mean values were also higher for males with relatively low gender differences; the statistical significance of the differences between genders was insignificant for SM and LD muscles and distinctly significant for TB muscles (table 3).

The quantity of proteins found in this study was slightly lower than the one assessed by other authors in Croatia, Poland, Italy [59, 2, 19,50], but the quantity of lipids was slightly higher; other studies found higher lipids content than in ours [2]. In the meat of hare shot in the eastern region of Croatia, chemical tests showed the following chemical average content: water $75.32 \%$, protein $23.08 \%$, fat $1.09 \%$, ash $1.16 \%$ [60]. In farmed hare meat from Italy there were found on average: $74.3 \%$ water, $22 \%$ crude protein contentin hind leg and respectively $23 \%$ in $L D$, and low ether extract content $(2.1 \%$ and $1.0 \%$ in hind leg and $\mathrm{LL}$, respectively), with ash content averaging $1.35 \%$ in the hind leg and $1.44 \%$ in LD [20].

Trocino etal., 2018 [20], found that the water and protein contents of hare meat decreased in the hind leg and LD with the age of hares, whereas the ether extract increased in LD only ( $0.92 \%$ to $1.11 \%)$. Consistent with Cobos et al. 1995 [52], Króliczewska et al., 2018 [2] wich examined the both wild leporids (rabbitand hare) they found a lower protein content for fore legs (TB muscles) than for either hind legs (SM muscles) or LD muscles. Our findings in the protein content of hare meatare in agreement with Trocino et al, 2018 [20], and lower then that found in other papers $[2,51,60]$.

The highest lipids quantity was determined for TB muscles (2.38\% for females), and the lowest was observed for LD muscles ( $1.52 \%$ for males). For all three muscle groups analyzed, the amount of lipid determined was higher for females compared to males. Variance analysis revealed very significant gender differences at the level of TB muscles and insignificant differences for the LD and SM muscles (table 4).

The fat content measured in this study is close to those determined by Mertin et al., 2012 [58], Skrivanko et al., 2008 [60], Vizzarri et al., 2014 [51], Trocino et al., 2018 [20], with small differences at the level of TB muscles from females where we determined slightly higher values (2.38\%). Kroliczewska et al., 2018 [2], found higher lipid 


\begin{tabular}{|c|c|c|c|c|}
\hline Muscles & Gender & $\bar{x} \pm s_{\bar{x}}$ & V\% & Anova \\
\hline \multirow{2}{*}{ SM } & Females & $2.01 \pm 0.09$ & 6.08 & \multirow{2}{*}{$\begin{array}{c}\mathrm{p}=0.593 \\
\text { n.s. }\end{array}$} \\
\hline & Males & $1.79 \pm 0.131$ & 11.12 & \\
\hline \multirow{2}{*}{ LD } & Females & $1.75 \pm 0.34$ & 23.56 & \multirow{2}{*}{$\begin{array}{c}\mathrm{p}=0.919 \\
\text { n.s. }\end{array}$} \\
\hline & Males & $1.52 \pm 0.13$ & 10.69 & \\
\hline \multirow{2}{*}{ TB } & Females & $2.38 \pm 0.12$ & 6.45 & \multirow{2}{*}{$\begin{array}{c}\mathrm{P}=4 \mathrm{E}-04 \\
* * *\end{array}$} \\
\hline & Males & $1.82 \pm 0.107$ & 9.05 & \\
\hline
\end{tabular}

M/F Males Females; n.s. (not significant) $=\mathrm{p}=0.05 ; *$ (significant)

$0.01 ; * *$ (distinct significant) $=0.01>\mathrm{p}>0.001 ; * * *$ (highly significant $)=0.001>\mathrm{p}$.

Table 4

THE FAT CONTENT (\%) OF HARE MEAT content in foreleg (2.30\%), hind leg (2.43\%) and LD (2.44\%) muscles than in present study.

The lowest water content was measured in TB muscles (74.35\% for females) because the amount of lipid determined was also highest for females in the same muscle group (2.38\%); for the other muscle groups analyzed, the mean values were higher, exceeding $75 \%$ for both sexes, with slightly higher values for males ( $75.20 \%$ for SM muscles, 75.15 for LD muscles and $75.17 \%$ for TB muscles).

The water content is very close to that determined by Skrivanko et al., 2008 [60] (75.34\% from muscle tissue, unspecified muscle groups), and in line with Trocino etal., 2018 [20] (that found 73.3-75.5 in adult and sub-adult hare hind leg and LD muscles); the amount of water found in present study was higher than that determined by Vizzarri et al., 2014 [51] (72.83\%), Kroliczewska et al., 2018 [2] ( $73 \%$ in foreleg, $74 \%$ in hind leg and $73.4 \%$ in LD muscles) and Mertin et al., 2012 [58] (72.83\%). Following the variance analysis test, insignificant differences were found between genders for LD and SM muscles, and very significant differences were found for TB muscles (table 5).

The ash content in the analyzed muscle groups was relatively close, with higher average values for males ( $1.271 \%$ for LD muscles, $1.251 \%$ for SM muscles and $1.267 \%$ for TB muscles), and following the variance analysis test were observed insignificant gender differences (table 6).

Higher values of ash content were determined in Poland (Kroliczewska et al, 2018 [2] found 2.30\% ash in foreleg, $2.43 \%$ ash in hind leg and $2.44 \%$ ash in LD muscle), and close values were determined in other studies from Croatia (Skrivanko et al., 2008 [59] found $1.16 \%$ ash) and Italy (Vizzarri et al, 2014 [51] found $1.06 \%$ ash in LD muscles and Trocino et al., 2018 [20] found 1.28-1.42\% ash in subadult and adult hares at the level of hind leg, including SM muscles, and 1.43-1.44 at the level of LD muscles).

The gross energy value supplied through hare meat consumption, showed the highest level for TB muscles collected from males $(168.5 \mathrm{Kcal} / 100 \mathrm{~g})$. For the other muscle groups, the mean values determined were lower but close (144.24-147.13 kcal/100 g), and statistical differences betw een the genders were insignificant (table 7).

Skrivanko et al., 2008 [59] found lower energy value for hare meat from Eastern Croatia ( $105.07 \mathrm{Kcal} / 100 \mathrm{~g}$ ), and Mertin et al., 2012 [58] found $112.13 \mathrm{kcal} / 100 \mathrm{~g}$ at the level of LD muscles collected from hare in South-West of Slovakia.

The average fatty acids content for all the three muscle groups studied shows predominantly higher values for males (table 8).

\begin{tabular}{|c|c|c|c|c|}
\hline \multirow{2}{*}{ Muscles } & Gender & $\bar{x} \pm s_{\bar{x}}$ & V\% & Anova \\
\hline \multirow{2}{*}{ SM } & Females & $75.10 \pm 0.12$ & 0.33 & $\mathrm{p}=0.604$ \\
& Males & $75.20 \pm 0.13$ & 0.41 & n.s. \\
\hline \multirow{2}{*}{ LD } & Females & $75.05 \pm 0.30$ & 0.79 & $\mathrm{p}=0.713$ \\
& Males & $75.15 \pm 0.10$ & 0.31 & n.s. \\
\hline \multirow{2}{*}{ TB } & Females & $74.35 \pm 0.13$ & 0.36 & $\mathrm{p}=1 \mathrm{E}-03$ \\
\cline { 2 - 4 } & Males & $75.17 \pm 0.10$ & 0.32 & $* * *$ \\
\hline
\end{tabular}

Table 5

THE WATER CONTENT OF HARE MEAT (\%)

$\mathrm{M} / \mathrm{F}=\mathrm{Males} /$ Females; n.s. (not significant) $=\mathrm{p}>0.05$;

$*$ (significant $)=0.05>p>0.01 ; * *$ (distinct significant $)=0.01>p>0.001 ;$

$* * *$ (highly significant) $=0.001>\mathrm{p}$.

\begin{tabular}{|c|c|c|c|c|}
\hline \multirow{2}{*}{ Muscles } & Gender & $\bar{x} \pm s_{\bar{x}}$ & V\% & Anova \\
\hline \multirow{2}{*}{ SM } & Females & $1.201_{ \pm} 0.31$ & 0.92 & $\mathrm{p}=0.586$ \\
& Males & $1.251 \pm 0.65$ & 1.89 & n.s. \\
\hline \multirow{2}{*}{ LD } & Females & $1.211_{ \pm} 0.3$ & 1.19 & $\mathrm{p}=0.315$ \\
& Males & $1.271 \pm 0.43$ & 2.45 & n.s. \\
\hline \multirow{2}{*}{ TB } & Females & $1.256 \pm 0.41$ & 1.21 & $\mathrm{p}=0.246$ \\
& Males & $1.267 \pm 0.28$ & 0.95 & n.s. \\
\cline { 2 - 4 } & &
\end{tabular}

$\mathrm{M} / \mathrm{F}=$ Males/Females; n.s. (not significant) $=\mathrm{p}>0.05 ;{ }^{*}$ (significant) $=0.05>$ $\mathrm{p}>0.01 ; * *$ (distinct significant $)=0.01>\mathrm{p}>0.001 ; * * 8$ (highly significant $)=$ $0.001>\mathrm{p}$

\begin{tabular}{|c|c|c|c|c|}
\hline Muscles & Gender & $\bar{x} \pm s_{\bar{x}}$ & $\mathrm{~V} \%$ & Anova \\
\hline \multirow{2}{*}{ SM } & Females & $143.81 \pm 1.32$ & 5.23 & \multirow{2}{*}{$\begin{array}{c}\mathrm{P}=0.354 \\
\text { n.s. }\end{array}$} \\
\hline & Males & $147.13 \pm 0.15$ & 4.73 & \\
\hline \multirow{2}{*}{ LD } & Females & $144.92 \pm 0.65$ & 8.15 & \multirow{2}{*}{$\begin{array}{c}\mathrm{p}=0.126 \\
\text { n.s. }\end{array}$} \\
\hline & Males & $144.24 \pm 0.76$ & 9.18 & \\
\hline \multirow{2}{*}{ TB } & Females & $161.94 \pm 0.48$ & 3.13 & \multirow{2}{*}{$\begin{array}{c}\mathrm{p}=0.349 \\
\text { n.s. }\end{array}$} \\
\hline & Males & $168.56 \pm 1.61$ & 2.62 & \\
\hline
\end{tabular}

Table 6

THE ASH CONTENT OF HARE MEAT (\%)

$\mathrm{M} / \mathrm{F}=$ Males/Females; n.s. (not significant) $=\mathrm{p}>0.05 ;{ }^{*}$ ( ignificant) $=0.05>$ $\mathrm{p}>0.01 ; * *$ (distinct significant) $=0.01>\mathrm{p}>0.001 ; * 8 *$ (highly significant) $=$ $0.001>\mathrm{p}$.

Table 7

THE ENERGY VALUE FOR HARE MEAT (Kcal/100 g) 
Highest value for saturated fatty acids SFA was highlighted at the level of palmitic acid $(339.02 \mathrm{mg} / 100 \mathrm{~g}$ for LD muscles collected from females). For MUFA, the highest average values were recorded for oleic acid: in LD muscles $352.51 \mathrm{mg} / 100 \mathrm{~g}$ for males and $278.67 \mathrm{mg} / 100 \mathrm{~g}$ for females, in SM muscles $307.58 \mathrm{mg} / 100 \mathrm{~g}$ for males and $241.18 \mathrm{mg} / 100 \mathrm{~g}$ for females, and in the TB muscles were registered $389.08 \mathrm{mg} / 100 \mathrm{~g}$ for males and $264.45 \mathrm{mg} / 100 \mathrm{~g}$ for females, with very significant statistical differences ( $p$ $<0.001$ ). Concerning the PUFA level, the highest values were determined for linoleic acid C18:2 n-6, with more than $500 \mathrm{mg} / 100 \mathrm{~g}$ for LD muscles $(593.23 \mathrm{mg} / 100 \mathrm{~g}$ for males and $501.63 \mathrm{mg} / 100 \mathrm{~g}$ for females), for SM with 556.63 $\mathrm{mg} / 100 \mathrm{~g}$ for males and $413.78 \mathrm{mg} / 100 \mathrm{~g}$ for females ( $\mathrm{p}<$ $0.001)$; also, for TB muscles was found $674.30 \mathrm{mg} / 100 \mathrm{~g}$ for males and $568.53 \mathrm{mg} / 100 \mathrm{~g}$ for females $(p<0.01)$.

After the evaluation of the statistical significance of differences on fatty acid content for TB and SM muscles, significant, distinct significant and very significant differences were observed for the majority of the fatty acids determined, and for LD muscles were found insignificant differences for 10 fatty acids from all 16 determined.

In this study, very favorable ratio of PUFA:SFA was found (in LD muscles 1.695 for males and 1.531 for females, in SM muscles 1.679 for males and 1.527 for females, and in TB muscles 1.885 for males and 1.820 for females). The
PUFA:SFA ratio was higher than that determined by Króliczewska et al., 2018 [2] (1.17 in LD muscles, 1.20 in hind leg muscles and 1.40 in fore leg muscles) and by Trocino et al., 2018 [20] (0.83 for hind leg of subadult and 1.70 for adult, and 1.16 for females and 1.18 for males, which are in line with the present study, that found for males' higher values).

After Kroliczewska et al., 2018 [2], which determined the quality and fatty acid profile of meat from hare and domestic rabbit, the high PUFA/SFA ratio in hare meat can be perceived as favorable for human health. Also, due to the high PUFA level in hare meat, the atherogenic index was significantly lower for hare meat than for rabbit meat, which should be attractive to consumers by the role of PUFA in reducing cardiovascular diseases; the thrombogenic index tended to be lower for hare meat than for rabbit meat. The low values of both the atherogenic and thrombogenic indices may be features specific to the species.

After Trocino et al., 2018 [20], the rate of SFA decreased in hind leg $(41.0 \%$ to $26.7 \%)$, and the rate of the PUFA increased (34.0\% to $45.3 \%$ ) with the age of individuals. In LD muscles, SFA (38.6\% to $42.9 \%)$ and MUFA (19.4\% to $27.2 \%)$ increased, whereas PUFA decreased $(42.0 \%$ to $30.1 \%$ ) when the age increased.

From the nutritional point of view the consumption of hare meat had a positive contribution in human health, by its high content of protein and low content of fat, with

Table 8

THE FATTY ACIDS CONTENT (mg/100 g) FOR LD, SM AND TB MUSCLES FROM HARES

\begin{tabular}{|c|c|c|c|c|c|c|c|c|c|c|c|}
\hline \multirow{2}{*}{\multicolumn{2}{|c|}{ Fatty acids }} & \multirow{4}{*}{$\begin{array}{l}\mathrm{M} / \mathrm{F}^{*} \\
\mathrm{M} \\
\mathrm{F}\end{array}$} & \multicolumn{3}{|c|}{ LD } & \multicolumn{3}{|c|}{ SM } & \multicolumn{3}{|c|}{ TB } \\
\hline & & & \multirow{2}{*}{$\frac{\bar{x} \pm s_{\bar{x}}}{2.79 \pm 1.06}$} & \multirow{2}{*}{$\begin{array}{l}\mathrm{V} \% \\
107.7 \\
\end{array}$} & \multirow{3}{*}{$\begin{array}{c}\text { Anova } \\
\mathrm{p}=0.099 \\
\text { n.s }\end{array}$} & \multirow{2}{*}{$\frac{\bar{x} \pm s_{\bar{x}}}{0.83 \pm 0.37}$} & \multirow{2}{*}{$\begin{array}{c}\text { V\% } \\
125.30 \\
\end{array}$} & \multirow{3}{*}{$\begin{array}{c}\text { Anova } \\
\mathrm{p}=0.151 \\
\mathrm{~ns}\end{array}$} & \multirow{2}{*}{$\frac{\bar{x} \pm s_{\bar{x}}}{1.08 \pm 0.52}$} & \multirow{2}{*}{$\begin{array}{c}\text { V\% } \\
17.7\end{array}$} & \multirow{3}{*}{$\begin{array}{c}\text { Anova } \\
p=0.181 \\
\text { n.s. }\end{array}$} \\
\hline \multirow{10}{*}{ SFA } & \multirow{2}{*}{$\mathrm{C} 14: 0$} & & & & & & & & & & \\
\hline & & & $0.29 \pm 0.17$ & 89.36 & & $0.54=0.61$ & 45.32 & & $0.62 \pm 1.89$ & 63.48 & \\
\hline & \multirow{2}{*}{$\mathrm{C} 15: 0$} & $\mathrm{M}$ & $9.13 \pm 0.57$ & 17.68 & \multirow{2}{*}{$\begin{array}{c}\mathrm{p}=0.089 \\
\text { n.s }\end{array}$} & $8.37 \pm 0.31$ & 10.58 & \multirow{2}{*}{$\begin{array}{c}\mathrm{p}=0.004 \\
* 8\end{array}$} & $9.91 \pm 0.26$ & 0.94 & \multirow{2}{*}{$\mathrm{p}=\mathrm{lE}_{8 * *} \mathrm{E}-04$} \\
\hline & & $\mathrm{F}$ & $7.57 \pm 0.04$ & 1.00 & & $6.68 \pm 0.04$ & 1.19 & & $7.64 \pm 0.05$ & 1.22 & \\
\hline & \multirow{2}{*}{$\mathrm{Cl} 16: 0$} & $\mathrm{M}$ & $323.41 \pm 15.21$ & 13.30 & \multirow{2}{*}{$\begin{array}{c}\mathrm{p}=0.499 \\
\mathrm{n.s}\end{array}$} & $313.84 \pm 9.17$ & 8.27 & & $302.17 \pm 4.88$ & 2.84 & $\mathrm{p}=0.061$ \\
\hline & & $\mathrm{F}$ & $339.02 \pm 5.05$ & 2.98 & & $279.73 \pm 2.48$ & 1.77 & $*$ & $286.77 \pm 2.61$ & 1.82 & n.s. \\
\hline & & $\mathrm{M}$ & $20.54 \pm 1.14$ & 15.75 & $\mathrm{p}=0.067$ & $19.26 \pm 0.31$ & 4.54 & $\mathrm{p}=3 \mathrm{E}-07$ & $22.18 \pm 0.45$ & 0.88 & $\mathrm{p}=0.004$ \\
\hline & Cl $7: 0$ & $\mathrm{~F}$ & $17.14 \pm 0.10$ & 1.18 & n.s. & $13.97 \pm 0.04$ & 0.56 & $\$ * *$ & $19.72 \pm 0.09$ & 0.86 & $* 8$ \\
\hline & & $\mathrm{M}$ & $117.74 \pm 5.21$ & 12.51 & $\mathrm{p}=0.039$ & $106.97 \pm 2.65$ & 7.02 & $\mathrm{p}=0.003$ & $123.10 \pm 2.66$ & 0.79 & $\mathrm{p}=9 \mathrm{E}-05$ \\
\hline & C18:0 & $\mathrm{F}$ & $99.84 \pm 0.39$ & 0.79 & 8 & $91.82 \pm 0.32$ & 0.69 & $\$ 8$ & $98.61 \pm 0.50$ & 1.01 & $8 * *$ \\
\hline & & $\mathbf{M}$ & 473.61 & & & 449.27 & & & 458.44 & & \\
\hline $10 t$ & $1 \mathrm{SHA}$ & $\mathbf{F}$ & 463.56 & & & 392.19 & & & 412.74 & & \\
\hline & & $\mathrm{M}$ & $27.44 \pm 1.39$ & 14.28 & $\mathrm{p}=0.098$ & $25.98 \pm 1.15$ & 12.47 & $\mathrm{p}=0.057$ & $30.16 \pm 0.65$ & 0.82 & $4 \mathrm{E}-05$ \\
\hline & C18:In- & $\mathrm{F}$ & $23.76 \pm 0.13$ & 1.06 & $*$ & $22.39 \pm 0.20$ & 1.75 & n.s. & $23.51 \pm 0.15$ & 1.25 & $* * *$ \\
\hline MUFA & & $\mathrm{M}$ & $352.51 \pm 24.73$ & 19.84 & $\mathrm{p}=0.066$ & $307.58 \pm 11.02$ & 10.13 & $\mathrm{p}=0.002$ & $389.08 \pm 14.01$ & 1.63 & 1E-04 \\
\hline & C18:In-9 & $\mathrm{F}$ & $278.67 \pm 2.07$ & 1.49 & n.s. & $241.18 \pm 2.31$ & 1.92 & $\$ \%$ & $264.45 \pm 2.35$ & 1.78 & $* * *$ \\
\hline & & $\mathbf{M}$ & 379.95 & & & 333.56 & & & 419.24 & & \\
\hline Tota & MUFA & $\mathbf{F}$ & 302.43 & & & 263.58 & & & 287.96 & & \\
\hline & & $\mathrm{M}$ & $593.23 \pm 32.79$ & 15.63 & $\mathrm{p}=0.083$ & $556.63 \pm 14.04$ & 7.14 & $p=4 E-05$ & $674.30 \pm 17.68$ & 0.68 & $p=0.002$ \\
\hline & C18: $2 n-6$ & $\mathrm{~F}$ & $501.63 \pm 1.49$ & 0.59 & n.s. & $413.78 \pm 2.40$ & 1.16 & $8 * *$ & $568.53 \pm 3.24$ & 1.14 & $* *$ \\
\hline & & $\mathrm{M}$ & $52.47 \pm 3.79$ & 20.42 & $p=0.141$ & $49.83 \pm 1.79$ & 10.18 & $p=2 E-04$ & $62.35 \pm 1.82$ & 0.76 & $p=0.002$ \\
\hline & C18:5n-3 & $\mathrm{F}$ & $43.68 \pm 0.26$ & 1.21 & n. 5 & $34.70 \pm 0.53$ & 3.07 & $8 * *$ & $51.05 \pm 0.36$ & 1.42 & $* *$ \\
\hline & & $\mathrm{M}$ & $9.95 \pm 0.36$ & 10.22 & $\mathrm{p}=0.117$ & $9.46 \pm 0.28$ & 8.30 & $\mathrm{p}=0.004$ & $10.74 \pm 0.20$ & 1.41 & $p=0.008$ \\
\hline & $C 20: 2 n-6$ & $\mathrm{~F}$ & $9.06 \pm 0.01$ & 0.32 & n.5 & $7.94 \pm 0.14$ & 3.50 & $* 8$ & $9.76 \pm 0.03$ & 0.59 & $* *$ \\
\hline & & $\mathrm{M}$ & $0.70 \pm 0.10$ & 39.73 & $p=6 \mathrm{E}-04$ & $0.66 \pm 0.05$ & 21.98 & $\mathrm{p}=0.003$ & $1.88 \pm 0.14$ & 14.34 & $p=0.041$ \\
\hline & $C 20: 3 n-6$ & $\mathrm{~F}$ & $0.94 \pm 0.20$ & 1.49 & $8 * *$ & $0.32 \pm 0.07$ & 42.86 & $* 8$ & $1.41 \pm 0.04$ & 5.58 & $*$ \\
\hline & & $\mathrm{M}$ & $62.97 \pm 0.73$ & 3.26 & $\mathrm{p}=0.006$ & $60.16 \pm 0.82$ & 3.86 & $\mathrm{p}=0.106$ & $56.12 \pm 0.34$ & 2.32 & $p=0.489$ \\
\hline PUFA & $0.20: 4 n-0$ & $\mathrm{~F}$ & $66.70 \pm 0.27$ & 0.80 & *8 & $62.41 \pm 0.64$ & 2.06 & n.s. & $56.48 \pm 0.09$ & 0.33 & n.s \\
\hline & & $\mathrm{M}$ & $3.23 \pm 0.29$ & 24.99 & $p=0.009$ & $2.83 \pm 0.51$ & 51.24 & $\mathrm{p}=0.966$ & $3.06 \pm 0.29$ & 19.65 & $p=0.668$ \\
\hline & C.20:5n-3 & $\mathrm{F}$ & $1.79 \pm 0.26$ & 28.69 & $\$ 8$ & $2.79 \pm 0.41$ & 29.07 & n.s. & $2.86 \pm 0.16$ & 11.44 & n.s. \\
\hline & & $\mathrm{M}$ & $16.95 \pm 0.09$ & 1.53 & $p=0.286$ & $16.85 \pm 0.14$ & 2.43 & $\mathrm{p}=0.329$ & $16.36 \pm 0.07$ & 1.00 & $p=0.004$ \\
\hline & C.22:4n-0 & $\mathrm{F}$ & $16.80 \pm 0.03$ & 0.34 & n.s. & $16.61 \pm 0.16$ & 1.93 & n.s. & $16.76 \pm 0.03$ & 0.32 & $* *$ \\
\hline & & $\mathrm{M}$ & $21.55 \pm 0.17$ & 2.23 & $p=4 E-07$ & $20.01 \pm 0.52$ & 7.35 & $\mathrm{p}=0.669$ & $12.75 \pm 0.57$ & 7.04 & $\mathrm{p}=0.030$ \\
\hline & C22:5n-3 & $\mathrm{F}$ & $24.51 \pm 0.11$ & 0.92 & $8 * *$ & $20.35 \pm 0.24$ & 2.35 & n.s. & $14.85 \pm 0.12$ & 1.59 & $*$ \\
\hline & & $\mathrm{M}$ & $41.54 \pm 1.48$ & 10.10 & $p=0.109$ & $37.85 \pm 0.61$ & 4.54 & $p=0.083$ & $26.40 \pm 1.15$ & 10.09 & $\mathrm{p}=0.112$ \\
\hline & $C 22: 0 n-3$ & $\mathrm{~F}$ & $45.44 \pm 0.79$ & 3.47 & n.5 & $39.89 \pm 0.88$ & 4.43 & $\mathrm{n} .5$ & $29.35 \pm 0.41$ & 2.76 & n.s \\
\hline Totz & PUFA & $\mathrm{M}$ & & .60 & & & 27 & & & 97 & \\
\hline 1ota & FUIA & $\mathrm{F}$ & & .61 & & & .80 & & & .06 & \\
\hline & & $\mathrm{M}$ & & 595 & & & 79 & & & 85 & \\
\hline & A:SFA & $\mathrm{F}$ & & 31 & & & 27 & & & 20 & \\
\hline
\end{tabular}

$\mathrm{M} / \mathrm{F}=\mathrm{Maleg} /$ Females; n.s. (not significant) $=\mathrm{p}>0.05 ; *$ (significant) $=0.05>p>0.01$

$* *$ (distinct significant) $=0.01>p>0.001 ; * * *($ highly significant $)=0.001>p$. 
favourable index of nutritive value of fat, i.e. proportion of essential amino acids and unsaturated fatty acids. Hare meat is full-value meat, easily digestible with typical aroma for the given species, and has finer muscle fibers than the meat of slaughter animals. Thanks to its relatively low-fat content venison ranks among the richest proteinaceous meatalong with fish meat, being higher than in farm animal [52].

Game meat usually comes from hunting, but according to results of recent papers [2, 20,52], hares farmed for restocking purposes may be used for meat production due to their favourable slaughter results (high dressing percentage) and carcass traits (high proportion of meat in hind legs and loins), as well as the high nutritional value of meat and favourable fatty acid composition. This fact would offer additional commercial opportunities, in addition to restocking, to hare farmers [20]. Under controlled conditions may be an alternative method for producing a high-quality meat that could increase the health of consumers [2]

\section{Conclusions}

The results obtained from the sensory analysis are relatively close as a score for the three muscle groups studied. The $\mathrm{pH}$ value was higher for TB muscles. The highest amount of protein was observed for LD muscles collected from males (21.65\%), that of lipids for TB muscles from females $(2.38 \%)$, and that of fatty acids were predominantly higher for males (for the most of the fatty acids determined). Very favorable ratio of PUFA:SFA was determined (in LD muscles 1.695 for males and 1.531 for females, in SM muscles 1.679 for males and 1.527 for females, and in TB muscles 1.885 for males and 1.820 for females). The variance analysis revealed insignificant differences by gender for the three muscle groups studied at the level of sensory analysis, of the $\mathrm{pH}$, of ash content and energy value, except for proteins, lipids and water content where onlyin the TB muscles, were observed very significant gender differences. Also, for some fatty acids, significant statistical differences between genders were observed, in all three muscle groups.

\section{References}

1.J O0, S.T., KIM, G.D., HWANG, Y.H., RYU, Y.C., Meat Scie., 95, 2013, p. 828.

2.KROLICZEWSKA, B., MIETA, D., KORZENIOW SKA, M., PECKA-KIEfB, E., ZACHWIEJA, A., Meat Scie., 145, 2018, p. 292.

3.MC MICHAEL, A.J ., BAMBRICK, H.J ., Public Health Nutrit,, 8, 2005, p. 341.

4.SIMOPOULOS A.P., The American J ournal of Clinical Nutrit., 6, 2002, p. 495.

5.MIERLITA, D., SIMEANU, D., POP, I.M., CRISTE, F., POP, C., SIMEANU,

C., LUP, F., Rev. Chim. (Bucharest), 69, no. 2, 2018, p. 453.

6.MIERLITA, D., POP, I.M., LUP, F., SIMEANU, D., VICAS, S.I., SIMEANU,

C., Rev. Chim. (Bucharest), 69, no. 1, 2018, p. 160.

7.IOSIF, L., GAMAN, L., CRIHANA, I., KOVACS, E., STOIAN, I., LUPESCU, O., Rev. Chim. (Bucharest), 67, no. 12, 2016, p. 2638.

8.TOCIU, M., TODASCA, M.C., STANESCU, M.D., Rev. Chim. (Bucharest), 68, no. 9, 2017, p. 2002.

9.POP, F., GIURGIULESCU, L., DUMUTA, A., VOSGAN, Z., Rev. Chim. (Bucharest), 64, no. 11, 2013, p. 1372.

10. COBZARU, C., APOSTOLESCU, N., APOSTOLESCU, G.A., MARINOIU, A., SILION, M., CERNATESCU, C., Rev. Chim. (Bucharest), 67, no. 4, 2016, p. 724.

11. DUMITRU, M.G., Rev. Chim. (Bucharest), 67, no. 6, 2016, p. 1127. 12. PAPUC, C., CRIVINEANU, M., NICORESCU, V., PAPUC, C., PREDESCU, C., Rev. Chim. (Bucharest), 63, no. 12, 2012, p. 1198. 13. LINGVAY, I., BUDRUGEAC, P., VOINA, A., CUCOS, A., MOSCALIUC, H., Rev. Chim. (Bucharest), 67, no. 11, 2016, p. 2202.

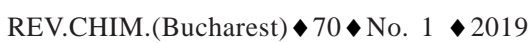

http://www.revistadechimie.ro
14. COPOLOVICI, D., BUNGAU, S., BOSCENCU, R., TIT, D.M., COPOLOVICl, L., Rev. Chim. (Bucharest), 68, no. 3, 2017, p. 507.

15. LUP, F., POP, I.M., SIMEANU, D., VICAS, S., SIMEANU, C., MIERLITA, D., Rev. Chim. (Bucharest), 69, no. 1, 2018, p. 222.

16.SIMEANU, C., SIMEANU, D., POPA, A., USTUROI, A., BODESCU, D., DOLIS, M.G., Rev. Chim. (Bucharest), 68, no. 5, 2017, p.1063.

17.SIMEANU, C., SIMEANU, D., DOLIS, M. G., Res. Journal of Biotech., 12, no. 2, 2017, p. 7.

18.NIK RAIKHAN, N.H., KHAIRUL IZWAN, A.R., International Journal of Conservation Science, 8, no. 3, 2017, p. 537.

19.PINHEIRO, V., OUTOR-MONTEIRO, D., SILVA, S., SILVA, J ., MOURAO, J.L., Archiv Tierz., 54, 2011, p. 625.

20.TROCINO, A., BIROLO, M., DABBOU, S., GRATTA, F., RIGO, N., XICCATO, G., Animal, 12, no 4, 2018, p. 864.

21.FAJARDO, V., GONZÁLEZ, I.I., ROJAS, M., GARCIA, T., MARTIN, R., Trends in Food Scie. Techn., 21, 2010, p. 408.

22.SANTOS C.G., MELO V.S., AMARAL J.S., ESTEVINHO L., OLIVEIRA M.B.P.P., MAFRA, I. Meat Scie., 90, 2012, p. 836.

23.DAL BOSCO, A., CASTELLINI, C., MUGNAI, C., Livestock Scie., 75, no. 2, 2002, p. 149.

24.DALLE ZOTTE, A., CULLERE, M., ALBERGHINI, L., CATELLANI, P., $\mathrm{PACl}, \mathrm{G}$. Czech J ournal of Animal Scie., 61, 2016, p. 383.

25.CULLEE M., DALLE ZOTTE A., Meat Sci., 143, 2018, p. 137.

26.D'AGATA M., PREZIUSO G., RUSSO C., DALLE ZOTTE, A., MOURVAKI E., PACl G., Meat Sci., 83, 2009, p. 691.

27.DAL BOSCO, A., CASTELLINI, C., BIANCHI, L., MUGNAI, C. Meat Scie., 66, 2004, 407.

28.DAL BOSCO, A., GERENCER, ZS., SZENDRO, ZS., MUGNAI, C., CULLERE, M., KOVÀCS, M., DALLE ZOTTE, A., Meat Sci., 96, 2014, p. 114.

29.DAL BOSCO, A., MATTIOLI, S., CULLERE, M., SZENDRO, ZS., GERENCSER, ZS., MATICS, ZS., CASTELLINI, C., SZIN, M., \& DALLE ZOTTE, A., Meat Sci., 143, 2018, p.46.

30.DALLE ZOTTE, A., CELIA, C., SZENDRO, ZS., Livestock Sci., 189, 2016 a, p. 82.

31.DALLE ZOTTE, A., CULLERE, M., REMIGNON, H., ALBERGHINI, L., PACl, G., World Rabbit Sci., 24, 2016 b, p. 145.

32.DALLE ZOTTE, A., CULLERE, M., SARTORI, A., DAL BOSCO, A., GERENCSER, Z., MATICS, Z., SZENDRO, Z., World Rabbit Scie., 22, 2014, p. 11.

33.CULLERE, M., DALLE ZOTTE, A., TASONIERO, G., GIACCONE, V., SZENDRÕ, Z., SZIN, M., ODERMATT, M., GERENCSER, Z., DAL BOSCO, A., MATICS, Z., Meat Sci, 141, 2018, p. 36.

34.CARDINALI, R., CULLERE, M., DAL BOSCO, A., et al., Livestock Scie., 175, 2015, p. 83.

35. BAVIERA-PUIG, A., BUITRAGO-VERA, J., ESCRIBA-PEREZ, C., MONTERO-VICENTE, L., World Rabbit Sci., 25, 2017, p. 95.

36.BIANCHI, M., PETRACCI, M., CAVANI, C., World Rabbit Scie., 17, 2009, p. 97.

37.CARDINALI, R., CULLERE, M., DAL BOSCO, A., MUGNAI, C., RUGGERI, S., MATTIOLI, S., DALLE ZOTTE, A., Livestock Sci., 17, 2015, p. 83.

38.CASTELLINI, C., DAL BOSCO, A., BERNARDINI, M., CYRIL, H.W., Meat Sci., 50, 1998, p. 153.

39.COMBES, S., POSTOLLEC, G., CAUQUIL, L., GIDENNE, T., Animal, 4, 2010, p. 295.

40.COMBES, S., INRA Prod. Anim., 17 no 5, 2004, p. 373.

41.COMBES, S., GONZALEZ, I, DEJ EAN, S., BACCINI, A.,J EHL, N, JUIN, H.,CAUQUIL, L., GABINAUD, B., LEBAS, F., LARZUL, C., Meat SCi., 80, 2008 , p. 835.

42.CORINO C., PASTORELLI G., PANTALEO L., ORIANI, G., SALVATORI G., Meat Sci., 52, 1999 , p. 285-289.

43.CORINO, C., MOUROT, J., MAGNI, S., PASTORELLI, G., ROSI, F., J ournal of Animal Sci., 80, 2002, p. 1020.

44.CORINO, C., FILETTI, F., GAMBACORTA, M., MANCHISI, A., MAGNI, S., PASTORELLI G., ROSSI, R., MAIORANO G., Meat Sci., 66, 2003, p. 97 45.VOLEK, Z., BURES, D., UHLIROVA, L., Meat Sci., 141, 2018, p. 50. 46.GONDRET, F., BONNEAU, M., INRA Prod. Anim., 11 no. 5, 1998, p. 335 .

179 
47.GONDRET F., COMBES S., LARZUL C., ROCHAMBEAU, H., Live. Prod. Sci., 76, 2002, p. 81.

48. GONDRET F., LARZUL C., COMBES S., ROCHAMBEAU H., Jour. Ani. SCi., 83, 2005, p. 1526.

49.GONDRET, F., COMBES, S., LEFAUCHEUR L., LEBRET B., Reprod. Nutr. Dev., 45, 2005, p. 86 .

50.HERMIDA, M., GAONZALES, M., MIRANDA, M., RODRIGUEZ-OTERO, J.L., Meat Sci., 73, 2006, p. 635.

51.VIZZARRI, F., NARDOIA M., PALAZZO, M., 2014. Archiv fur Tierz., 57, p. 1.

52.COBOS, A., DE LA HOZ, L., CAMBERO, M. I., ORDONEZ, J. A., Zeitschrift für Lebensmittel Untersuchung und Forsch., 200, 1995, p. 182-185.

53.NISTOR, E., BAMPIDIS, V.A., PACALA, N., PENTEA, M., TOZER, J., PRUNDEANU, H., J ournal of Animal Production Adv., 3, 2013, p. 172. 54. HERNÁNDEZ, P., Revista científica de nutrición. 154, no. 8, 2007, p. 33.

55.HERNANDEZ, P., CESARI, V., PLA, M., Intern. Congress of Meat Sci. and Tech., 2007, p. 367.

56.HERNANDEZ, P., CESARI, V., BLASCO A., Meat Sci., 78, 2008, p. 485. 57.VALENCAK, T.G., ARNOLD, W., TATARUCH, F., RUF, T., J Comp Physiol B., 173, 2003, p. 695.

58.MERTIN, D., SLAMEĖKA, J., ONDRUSKA, I., ZAUJ EC, K., JUREÍK, R., GASPARIK, J., Slovak J ournal of Animal Scie., 45, no. 3, 2012, p. 8995.

59.PAPADOMICHELAKIS, G., ZOIDIS, E., PAPPAS, A.C., HADJ IGEORGIOU, I., Meat Scie., 134, 2017, p. 158.

60.SKRIVANKO, M., HADZIOSMANOVIC, M., CVRTILA, Z., ZDOLEC, N., FILIPOVIC, I., KOZAEINSKI, L., FLORIJ ANĖIC, T., BOSKOVIC, I., Archiv fur Lebensmittelhygiene, 59, 2008, p. 180.

61. STRMISKOVA, G., STRMISKA, F., Die Nahrung, 36, 1992, p. 307.

62.*** AOAC, Official Methods of Analysis of the AOAC. $15^{\text {th }}$ ed., Association of Official Analytical Chemists, Arlington, VA, 1990, USA. 63.MACRI, A., OANA, L., STEFAN, R., DINCA, A., MORAR, M.V., PASCA, I., SZAKACS, A., MOLDOVAN, L., Bulletin of the University of Agricultural Science and Veterinary Medicine Cluj-Napoca, Veterinary Medicine Series, 67, no. 1, 2010, p. 101
64.MACRI, A., MORAR, M.V., SZAKACS, A., TARTA, I.A., BELE, C., SCURTU, I., POPA, C.T., DANCEA, Z., Bulletin of the University of Agricultural Science and Veterinary Medicine Cluj-Napoca, Veterinary Medicine Series, 67, no. 1, 2010, p. 105.

65.PLA, M., Livestock Scie.,115, 2008, p. 1.

66.ZOMENO, C., BLASCO, A., HERNANDEZ, P., J ournal of Animal Scie., 88, 2010, p. 3419.

67.ZOMENO, C., HERNANDEZ, P., BLASCO, A., World Rabbit Scie., 19 no 4, 2011, p. 203.

68.ZOMENO, C., JUSTE, V., HERNANDEZ, P., Meat Scie., 91 no 2, 2012, p. 155.

69.ZOMENO, C., HERNANDEZ, P., BLASCO, A., Journal of Ani. Scie., 91 no 9, 2013, p. 4526.

70.MARTINEZ-ALVARO, M., HERNANDEZ, P., BLASCO, A.J., Anim. Sci., 94, 2016a, p. 4993.

71.MARTíNEZ-ALVARO M., PENALBA, V., BLASCO, A., HERNANDEZ, P.j. Anim. Sci., 94, 2016b, p. 5137.

72.MARTINEZ-ALVARO, M., HERNANDEZ, P., AGHA, S., BLASCO, A., Meat Sci., 139, 2018, p. 187-191.

73MARTINEZ-ALVARO, M., HERNANDEZ, P., World Rabbit Sci. 26, 2018, p. 43.

74.ARIÑO, B., HERNANDEZ, P., BLASCO, A., Meat Scie., 73, 2006, p. 687.

75.ARINO, B., HERNANDEZ, P., PLA, M,. BLASCO, A., Meat Scie., 75 no 3, 2007, p. 494.

76.PLA, M., PASCUAL, M., ARINO, B., World Rabbit Sci., 12, 2004, p. 149.

77.PLA, M., HERNANDEZ, P., ARINO, B., RAMIREZ, J.A., DIAZ, I. 2007. Food Chem., 100, p. 165.

78.PRADHAN, A.A., RHEE, K.S., HERNANDEZ, P., Meat Sci., 54, 2000, p. 385.

79.RAMIREZ, J.A., DIAZ, I., PLA, M., GIL, M., BLASCO, A., OLIVER, M.A., Food Chem., 90, 2005, p. 251.

80.HERNANDEZ, P., PLA, M., OLIVER, M.A., BLASCO, A., Meat Sci., 55, 2000, p. 379.

81.HERNANDEZ, P., LOPEZ, A., MARCO, M., BLASCO, A. World Rabbit Sci., 10, 2002, p. 139.

82.VAN LAACK RL, LANE JL. Poult Sci., 79, no. 1, 2000 p. 105.

Manuscript received: 16.07.2018 